\title{
The Final Stages of Vegetal Dynamics in the Lesser Antilles (A Few Theories)
}

\author{
Philippe Joseph \\ Doctor and Professor, Biogeography, Ecology \& Botany, University of the French West Indies, UMR ESPACE DEV/ BIORECA
}

\begin{abstract}
In the Lesser Antilles, from the 17th century takeover up to the present day, mankind has altered the natural environment with frequent and intense distinguished methods. Today's vegetation is resolved in a phytocenotic complex in which shrub, pre-forest and young secondary forest cover dominates. At present, there are few examples of mature sylva, and they are often located in zones which are unsuitable for societal development. Thanks to these (mature sylva) we have been able to outline the main traits of the climax, or climax community, that we have called "structural peak". The latter would represent optimal ecosystemic evolution. In this review article, in the light of data analysis from previous and recent floristic studies, the spatial heterogeneities and complexities of the final stages of vegetation evolution have been described.
\end{abstract}

Keywords: Lesser Antilles, vegetation, biodiversity, climax

\section{Introduction}

In regard to vegetal succession and thus the climax, the definitions, analyses and assertions are highly varied [1-7]. According to schools of thought, the climax concept takes various forms and is steeped in controversy [8-11]. The climax of a type of vegetation is the end of a successional process which would have taken place over a long period of time, in which associations of species with highly varied ecological strategies have been assembled successively, but not always continuously [11-15] (Figure 1, Inset 1). Vegetal succession obeys the ecosystem auto-organisation dynamic, which depends on biophysical factors [16- 21]. Abiotic factors define the ecosystemic potential of biotopes alongside, for each phase of evolution, the importance of the ecological profiles of taxa in comparison with each other [22-24] (Figure 2). Consequently, floristic formations called climax species are composed of species which are highly specialised and not accustomed to using environmental resources [25-28] (Figure 3). Climax species vegetation in the Lesser Antilles, which is forested, bares these characteristics [29]. The plants that compose it are very diverse, as much in their taxonomic, physiological, anatomical and morphological make up as in the diasporese means of dissemination [30-36]. With the help of data gathered in recent and previous synchronic studies on diverse structural and functional aspects of the flora in the Lesser Antilles, we have been able to retrace this highly complex state $[32,37]$.We also referred to information from initial discoveries and nature columnists. The difficulty of this work lies in the fact that todayes vegetation in the Lesser Antilles is breaking down and regressing [38]. Most vegetation communities that make it up are physiognomic types, as well as dynamic facies that contribute to greatly diverse landscape formations [39]. The phenomenon of ecosystemic regression began at the take over of the West Indies ${ }^{\text {ee }}$ archipelago in the $17^{\text {th }}$ century. The species that dominate today were, before the discovery of the Americas, from a demographic view point, very small and colonised unique sites (ecological sanctuaries) that are associated with constant destabilisation: ridges or crests exposed to wind, windfall, recurrent landslide zones on slopes, etc. (Figure 2). Despite the absence of relevant data, there is every reason to believe that the absence of the original eco-climatic conditions, the inertia required to maintain primitive vegetal ecosystems no longer exists because of human impact.

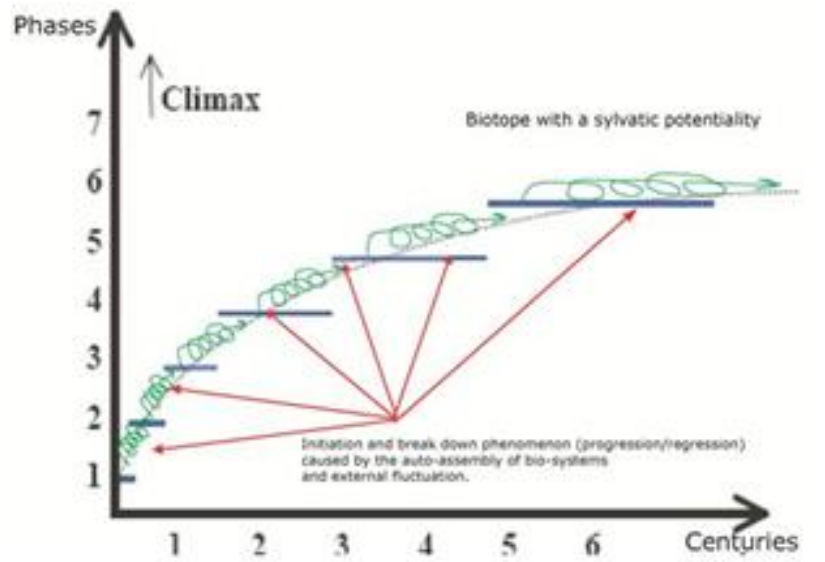

Figure 1: Graph showing the speed succession of evolution phases (According to OZENDA 1982)

Inset 1

The transformation whereby the different vegetal associations succeed each other is slow. After a certain period of time, the forest can reach a steady state: the climax (if there is no human and/or natural interference), striking a balance with the outer environment. Nevertheless, inside the climax species ecosystem and at all integration levels, the biological variability (species, density, age, phenophases, etc.) remains important. In general, the evolution pattern towards the climax includes the following succession: pioneer vegetation communities (herbaceous, shrubby and pre-forest species), post-pioneer vegetation communities (young and secondary forests) then climax species (preclimax species and climax species forest). The different development phases are not at all linear and succeed each other more and more slowly; the optimal organisation (climax) is reached after several centuries. On the scale of a forest massif, particularly in the wet tropics, singular evolutions form a network system where the eco-units, according to the fluctuation of eco-climatic factors, are affected by regression or progression dynamics. The forest massif can be considered as climax species when the 


\section{International Journal of Science and Research (IJSR) \\ ISSN (Online): 2319-7064}

Index Copernicus Value (2013): 6.14 | Impact Factor (2014): 5.611

majority of the eco-units have reached their final evolution phase, no matter which floristic cortege dominates. In reality, on the scale of a regional forest, the climax is a "polyclimax" which has metastable components due to the permanent changes.

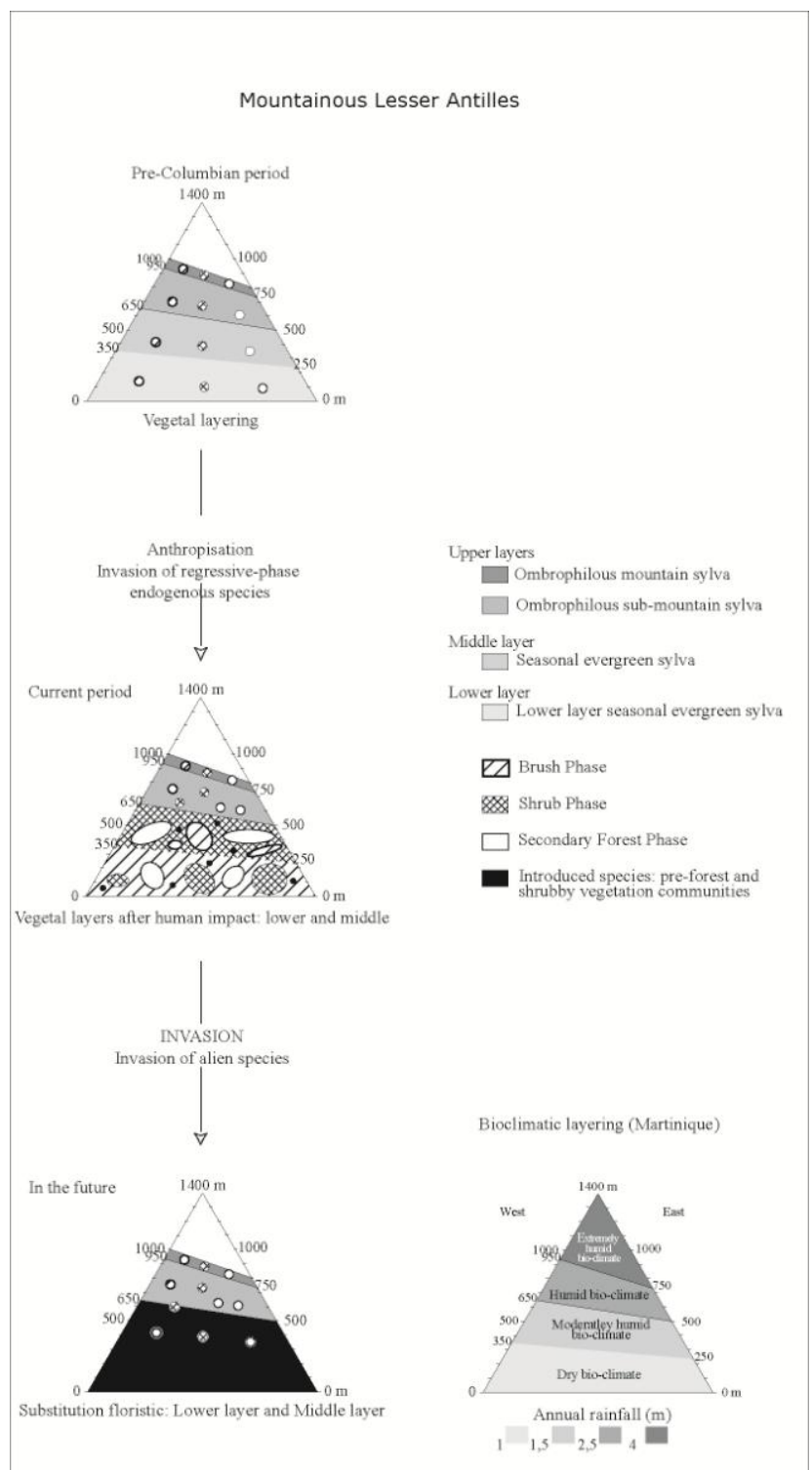

Figure 2: Vegetation evolution

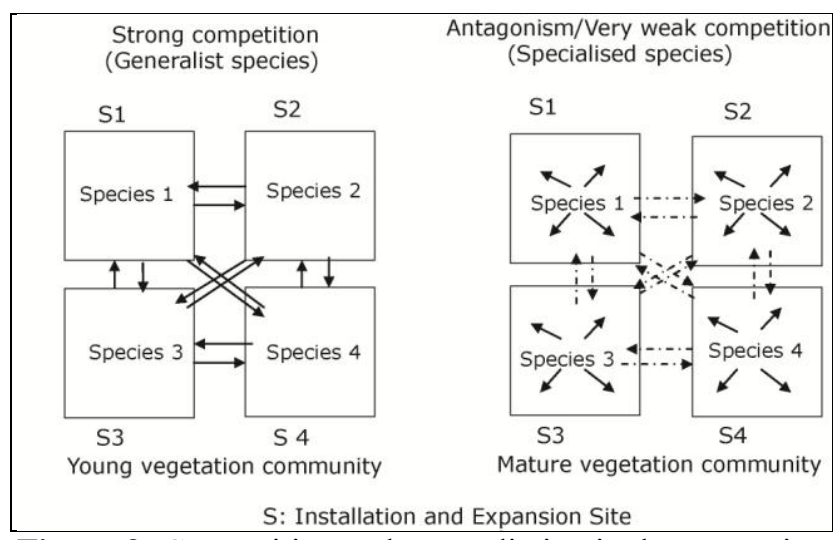

Figure 3: Competition and contradiction in the vegetation community

\section{Some Features of Climax Species Vegetation in the Lesser Antilles}

In the West Indies the ecosystemic potential is sylvatic, in other words, the peak of vegetal succession is the forest [4042]. In the climax species entity, the maximum organisation, yet metastable, has been reached and the most specialised floristic associations dominate [30, 39]. The intra-forest microclimatic conditions are different to those typical of the macroclimate [43]. The degree of stability (resilience) of the system is high [44-48]. It is known to be homeostatic and the variations, particularly daily [Variations between day and night still called diel variation], of the regional climate are heavily buffered in its inner environment [49]. Without interference unrelated to turn over [To internal bio-systemic fluctuations], particularly in chablis (deadwood), the conditions aid the structure in place to be repeated $[43,50]$. Concerning the edaphic component, things appear to be identical. In theory, in terms of abiotic factors (depth, texture, water dynamic, nutrient potential (fertility), water potential) and biotic factors (flora, micro-fauna, macrofauna, meso-fauna, root tissue) there is extreme organisation in the topsoil [51]. Above all, the climax is known for being highly complex. Infact, the evolution of the topsoil is integral to that of the vegetation [52] and a soil climax would correspond to a vegetal climax. Of course, in the climax, the most specialised species are seen first [51]. Yet, in the climax species entity named "forest aisle matrix", with its differing structural, functional and floristic features, all dynamic strategies can be observed (Table1, Figure 4). Reference could be made to a climax dynamic [30, 39]

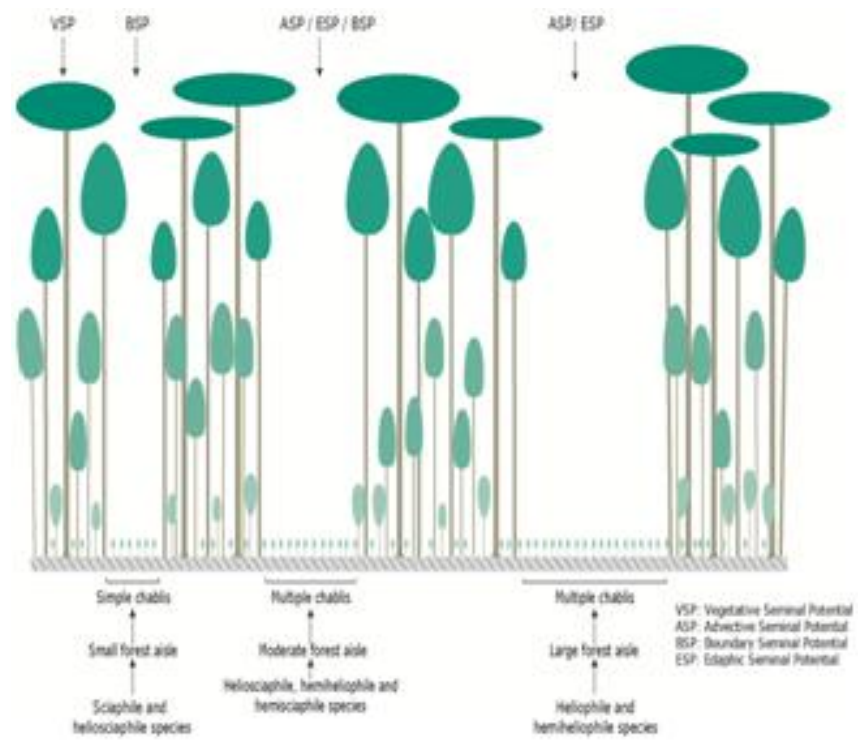

Figure 4: Ecological profiles of mature forest chablis 


\section{International Journal of Science and Research (IJSR) \\ ISSN (Online): 2319-7064 \\ Index Copernicus Value (2013): 6.14 | Impact Factor (2014): 5.611}

Table 1: Examples of sylvatic climax species or sub-climax species eco-units of varying floristic composition Dominant corteges / Taxa in dominance order / Dynamic phases / authors

Sideroxylon foetidissimum (Meg), Manilkara bidentata (Meg), Pimenta racemosa (Ma), Hymenaea courbaril (Meg), Guaiacum officinale (Me) (plausible Climax: FIARD, 1994 \& JOSEPH, 1997)

Cassipourea guianensis (Me), Manilkara bidentata (Meg), Ormosia monosperma (Me), Licaria sericea (Ma), Licania leucosepala (Ma) (plausible Climax: FIARD, 1994 \& JOSEPH, 1997)

Ocotea leucoxylon (Ma), Ormosia monosperma (Ma), Calophyllum calaba (Me), Andira inermis (Ma), Manilkara bidentata (Meg) (plausible Climax : FIARD, 1994 \& JOSEPH, 1997)

Pouteria multiflora (Meg), Brosimum alicastrum (Meg) et Chrysophyllum argenteum (Me) (Climax : FIARD \& ROLLET,1984)

Pouteria multiflora (Meg), Guarea glabra (Me), Sideroxylon foetidissimum(Meg), Chrysophyllum argenteum (Me) et Hymenaea courbaril(Meg) - (Climax : BEARD, 1949)

Hymenaea courbaril (Meg), Inga laurina (Meg), Pouteria multiflora (Meg), Pisonia Fragrans (Me) - (Sub-climax : FIARD \& JOSEPH, 1997)

Guarea glabra (Me), Andira inermis (Ma), Calophyllum calaba (Me), Brosimum alicastrum (Me), Buchenavia tetraphylla (Meg) - (Climax : FIARD, 1994) Pouteria multiflora (Meg), Pouteria semecarpifolia (Meg), Sterculia caribaea(Ma), Licania sericea (Ma), Maytenus guanensis (Me), Ilex nitida (Ma) et Ocotea leucoxylon (Ma) - (Sub-climax : FIARD, 1994)

Sloanea dentata (Meg), Coccoloba diversifolia (Me) - (Sub-climax ; J.S. BEARD: 1949) Nevis / upper

Sloanea dentata (Meg), Dacryodes excelsa (Meg), Beilschmiedia pendula (Ma) Nevis / upper (Climax ; J.S. BEARD, 1949)

Dacryodes exelsa (Meg), Sloanea dentata (Meg), Ormosia monosperma (Ma), Simarouba amara (Ma), Guatteria caribaea (Me), Sloanea berteriana (Meg), Sapium caribaeum (Ma) - (Sub-climax ; BEARD,1949)

Dacryodes excelsa (Meg), Tapura latifolia (Ma), Sloanea massoni \& Sloanea berteriana (Meg)?, Sterculia caribaea (Ma) - (Climax ; BEARD, 1949)

Dacryodes excelsa (Meg), Tapura latifolia (Ma), Licania ternatensis(Ma), Pouteria pallida (Meg), Sterculia caribaea (Ma), Micropholis guyanensis (Meg), Sloanea caribaea (Meg), Guatteria caribaea (Me), Euterpe dominicana (Me) (Climax : $B E A R D, 1949)$

Dacryodes excelsa (Meg), Sterculia caribaea (Ma), Tapura latifolia(Me), Talauma dodecapetala (Meg) - (Climax ; BEARD, 1949)

Dacryodes excelsa (Meg), Pouteria pallida (Meg), Licania ternatensis (Ma), Manilkara bidentata (Meg), Micropholis guyanensis (Meg), Talauma dodecapetala (Meg), Sloanea caribaea (Meg) - (Climax ; BEARD,1949)

Dacryodes excelsa (Meg), Licania ternatensis (Meg), Guatteria caribaea (Me), Micropholis guyanensis (Meg), Sloanea caribaea (Meg)-(Climax ; BEARD,1949) Amanoa caribaea (Meg), Tapura latofolia (Ma), Dacryodes excelsa (Meg), Licania ternatensis (Ma), Sloanea dentata (Meg), Guatteria caribaea (Me), Ormosia monosperma (Ma), Pouteria pallida (Meg), Rudgea citrifolia (Mi), Sideroxylon foetidissimum (Ma)- (SUb-climax; STEHLE, 1941)

Amanoa caribaea (Meg), Tapura latifora (Ma), Dacryodes excelsa (Meg), Guatteria caribaea (Me), Licania ternatensis(Ma) - (Climax ; STEHLE, 1941) Talauma dodecapetala (Meg), Chimarrhis cymosa (Ma), Prestoea montana(Mi), Marila racemosa (Mi), Ocotea dominicana (Me), Sloanea dussii (Meg), Sloanea massoni (Meg), Sterculia caribaea (Ma), Lonchocarpus pentaphyllus (Me)-(Subclimax ;FIAD, 1994)

Chimarrhis cymosa (Ma), Sloanea caribaea (Meg), Talauma dodecapetala(Meg) Prestoea montana (Mi), Sloanea dentata (Meg), Sloanea massoni (Meg), Sterculia caribaea (Ma), Aniba bracteata (Me) - (Sub-climax ;FIARD, 1994)

Talauma dodecapetala (Meg), Dacryodes excelsa (Meg), Tapura latifolia (Ma), Sloanea massoni(Meg), Prestoea montana (Mi), Ormosia monosperma (Ma), Martinique / upper Sterculia caribaea (Ma)- (Climax ;FIARD, 1994)

Dacryodes excelsa (Meg), Tapura latifolia (Ma), Cordia sulcata (Mi), Sloanea massoni (Meg), Sterculia caribaea (Ma), Chimarrhis cymosa (Ma), Pouteria multiflora (Meg), Pouteria pallida (Meg), Talauma dodecapetala (Meg), Pouteria semecarpifolia (Meg), Aniba bracteata (Me), Guarea kunthian a (Mi) -

(Sub-climax;FIARD, 1994)

Meg: Megaphanerophyte, Ma :Macrophanerophyte,

Me : Mesophanerophyte, Mi : Microphanerophyte

\section{Volume 4 Issue 11, November 2015 www.ijsr.net} supérieur

Saint Lucia / upper

Saint Lucia / upper

Guadeloupe / upper Guadeloupe / upper Martinique / upper Martinique / upper

Martinique / upper 1

\begin{tabular}{|l|}
\hline $\begin{array}{l}\text { Insular system/ } \\
\text { vegetal layer }\end{array}$ \\
\hline $\begin{array}{l}\text { Martinique / } \\
\text { Iower layer }\end{array}$ \\
\hline $\begin{array}{l}\text { Martinique / } \\
\text { middle layer }\end{array}$ \\
\hline $\begin{array}{l}\text { Martinique / middle } \\
\text { (upper layer) }\end{array}$ \\
\hline $\begin{array}{l}\text { Saint-Vincent / } \\
\text { middle }\end{array}$ \\
\hline middle \\
\hline Martiniquent / \\
\hline Saint-Vincent / \\
middle
\end{tabular}




\section{International Journal of Science and Research (IJSR) \\ ISSN (Online): 2319-7064}

Index Copernicus Value (2013): 6.14 | Impact Factor (2014): 5.611

End-phase or climax species forest communities are selfmaintained and this conservation relates to that of herbaceous grass formation, which repeats itself over a long period of time [28, 53]. Nevertheless, herbaceous formation differs here as it is subject to elimination by replacement. As a matter of fact, when shrubs appear in grassland, they become gradually denser, develop larger biomasses and spark progressive vegetal succession. Conversely, without any natural deep or anthropogenic aggression, a climax species forest formation remains stable over time. The homeostatic nature of mature sylva makes changes extremely slow. Therefore, the inertia of the climax species sylva allows it to adapt itself. It can permanently establish itself in new climatic conditions, different from the climate where it originally developed [In this state, it is obvious that human activity is very harmful and can lead to irreversible deregulation causing floristic composition, a reference for previous eco-climatic conditions, to disappear permanently] $[38,54]$.

The autonomy of the intra-forest environment vis-à-vis the macroclimate, and the structural and floristic integrity, which is mainly safeguarded by the systems ${ }^{\text {ee }}$ inertia [The climax species forest integrates an extreme organism doted with independence as regards the surrounding environment, able to establish itself permanently when its initial growth conditions no longer exist], are all aspects specific to the Lesser Antillese pre-Columbian sylva [43]. Today, some profoundly weakened primary forests still remain on mountainous areas that are unsuitable for the development of human societies. These forest remains can often be found in protected areas (Martinique, Dominica, Guadeloupe, Saint Lucia, Saint Vincent) [55] (Figures 5a, b ,c \& d).
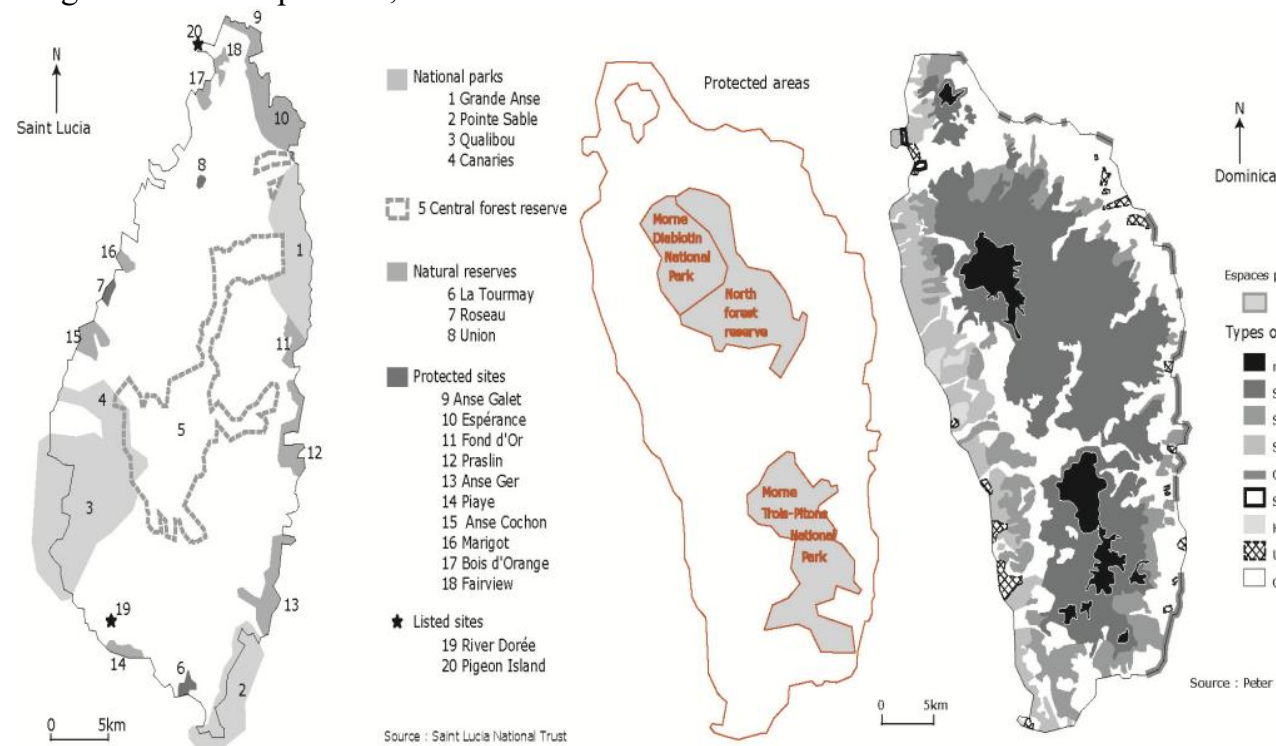

Figures 5a \& b: National parks and nature reserves in Saint Lucia and Dominica
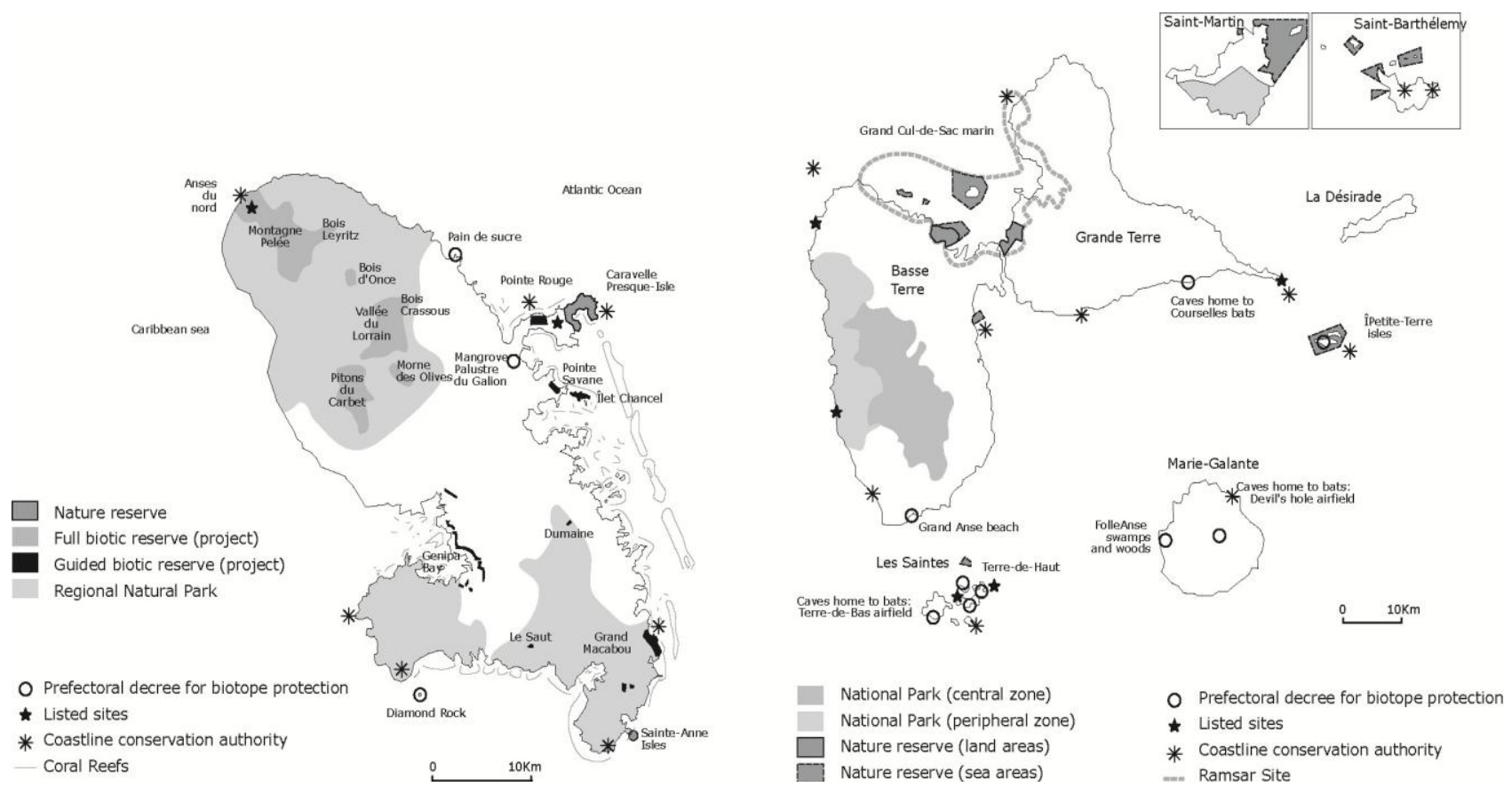

Figures 5c \& d: National parks and nature reserves in Martinique, Guadeloupe, Saint Martin and Saint Barthélemy 


\section{International Journal of Science and Research (IJSR) \\ ISSN (Online): 2319-7064 \\ Index Copernicus Value (2013): 6.14 | Impact Factor (2014): 5.611}

The structural peak of vegetation: a phytocenotic complex. The concept of climax must be put into perspective and a flexible approach must be adopted, alike a perfect balance between vegetal ecosystems and climate or bioclimatic site conditions. The high structuring of primitive forest communities in the West Indies has resulted in a phase offset between the intra-forest microclimate and the macroclimate. This phase offset causes significant transfers of species from their original areas [These are determined by the climate] towards their marginal areas [These are determined by the high structuring or complexity of the ecosystem (ecosystemic correction)]: for example, from the middle layer to the lower layer. This resembles the vegetation inversion phenomenon, leading to ecosystemic correction caused by the foliage biomass layering [The strata are as many exchange surfaces] [49].

The climax can thus be seen as the maximal balance between sylvatic eco-units and environmental conditions. The mosaic of biological communities, showing the spatial heterogeneities underlying the ecological factors, is made up of matrix plots [Matrix floristic units or eco-units made up of antagonistic specialised species]which are narrowly differentiated in terms of their complexity. On top of these, forest aisles [Chablis floristic units or eco-units made up of competing generalist species] of varying age, structure, dimension and composition are added (Figure 6).Dominant vegetal corteges can identify a forest cover's floristic units or eco-units. Nevertheless, the latter, under the influence of a specific bio-climate, can only be distinguished by its ecological group, composed of specific taxa from varied topographic facies and multiple phases of evolution [30, 39].

On a regional level, toposequence characteristics, diverse macroclimates and edaphic variables accentuate the plural nature of the climax. It is this phenomenon which has been and which still is at the origin of the great biodiversity of the Lesser Antilles se sylvatic climax species formations. The high number of floristic arrangements or combinations shows the irregularity of environmental factors.

In reality, the climax is a "polyclimax" as it presents a large multiplicity of highly specialised end-phase matrix vegetal units (Figure 7).

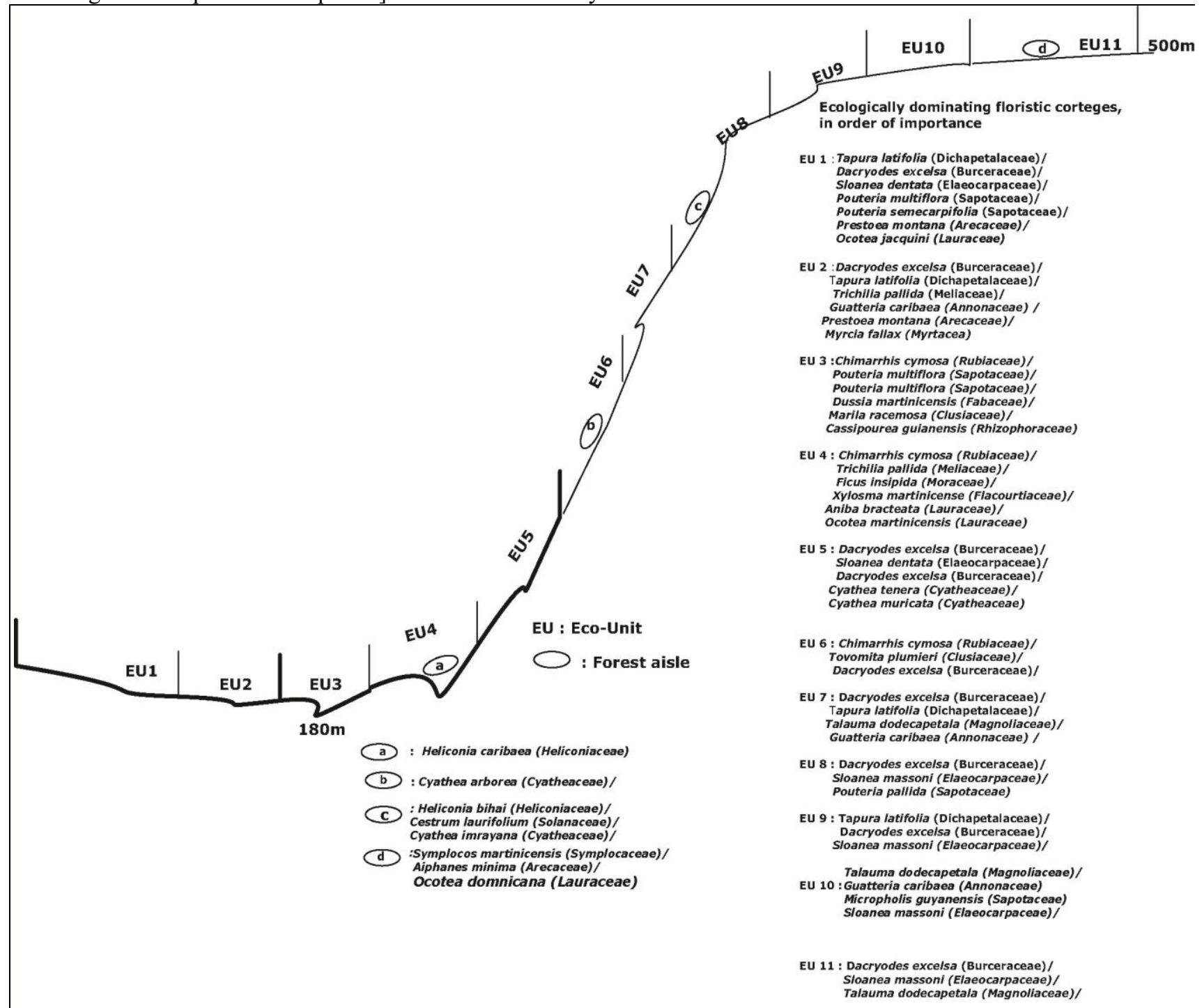

Figure 6: Graph showing the altitudinal variation of eco-units

Volume 4 Issue 11, November 2015 www.ijsr.net 


\section{International Journal of Science and Research (IJSR) \\ ISSN (Online): 2319-7064}

Index Copernicus Value (2013): 6.14 | Impact Factor (2014): 5.611

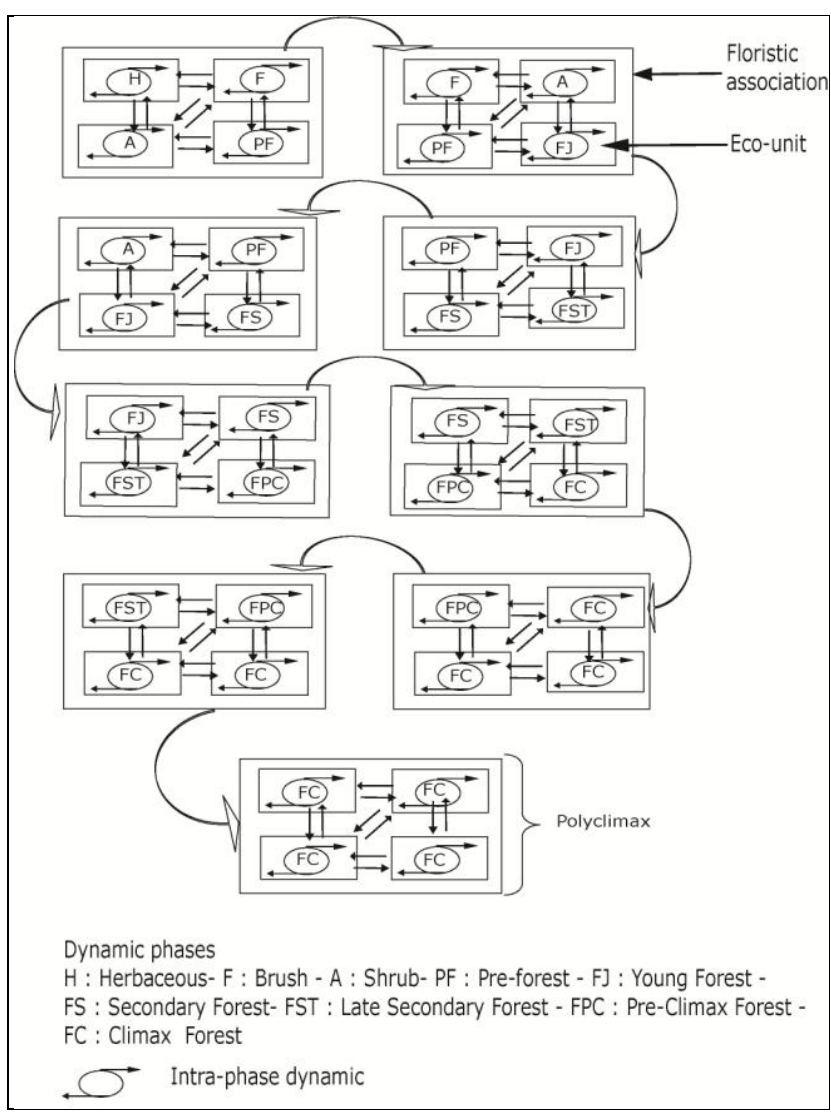

Figure 7: Theoretical presentation of the progressive evolution of floristic eco-units

At the optimal evolution phase there is still a tendency to reduce this intrinsic factorial heterogeneity. For example, the differences caused by the edaphic system and the topography, creating microclimates or even single microenvironments [56], can be compensated for by the extreme organisation of vegetal climax species communities. Moreover, it is the ecosystemic correction that conditions the spatial floristic transfer described earlier. Formerly, this had resulted in a certain homogenisation of adjacent vegetal layers.

Thus, it seems that the climax or even the "polyclimax" of the primitive vegetation of the Lesser Antilles rendered a unique ecosystemic evolution on the scale of climatic change [38]. That is to say that the dynamic directions which enabled it to occur were involved in a distinctive history of the biosphere, in very specific environmental and climatic conditions [57]. If we acknowledge the systemic functioning of the vegetal formations at the scale of the station, it is also necessary to acknowledge a higher level of integration [45]. The upkeep of large regional biological balance results from the interaction of varied biotic communities and ecosystems. The recent history of Lesser Antilles"e vegetation is distinguished by human activity varying in frequency and intensity [The various physiognomic types resulting from highly diverse human activity indicate as many dynamic phases.

Particularly in protected areas and according to the hypothesis where human impact disappears [Particularly in protected areas], future vegetation would be identified, in sectors where it could reach its dynamic peak, by multifaceted forest groups: structural analogues of the preColumbian era"s "polyclimax". The differentiating factor, which will draw a distinction between the next hypothetical climax, will be primarily linked to floristic composition.

\section{The Feasible Evolution of Vegetation in the Lesser Antilles}

\subsection{What could the structural peak or climax become in the future?}

Therefore, in the protected zones, evolving from a current profoundly depleted floristic potential, the newly formed floristic climax species combinations will be completely different from those in the earlier climax. In this final phase, all specific associations will be attained, specific to each stage of the gradient dynamic (Figure 8a). For each of these, their installation and expansion sites will depend largely on the structure of the natural regional factors [58]: more precisely the geomorphological formation and the climate (Figure 9). Other important factors that should be associated with these interact and create a factorial area (precipitation, cloud, evaporation, evotranspiration, topography, pellicular and underground water circulation, soil formation and vegetation) $[38,56,59]$. This factorial area evolves at the same time as the changes in the floristic cover and the edaphic system (Figure 8b): generally these two components of the ecosystem vary simultaneously. Theoretically, because successive factorial areas that intersperse the gradient dynamic will differ, the future climaxes of protected areas will not be the same as the previous ones (Figure 8b). 


\section{International Journal of Science and Research (IJSR)}

ISSN (Online): 2319-7064

Index Copernicus Value (2013): 6.14 | Impact Factor (2014): 5.611

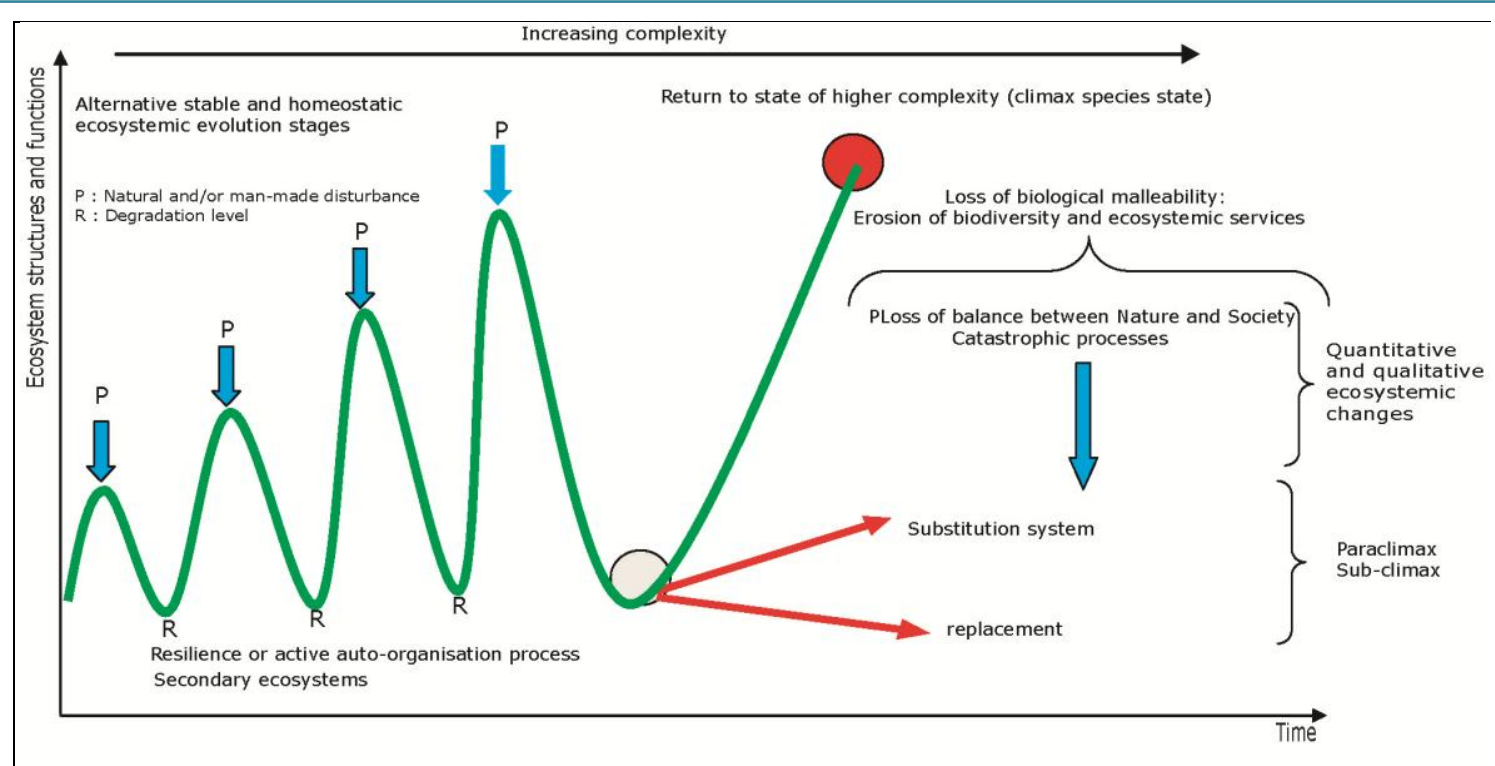

Figure 8a: Theoretical evolution of the ecosystem (modified from Dobson et al. 1997 [60])

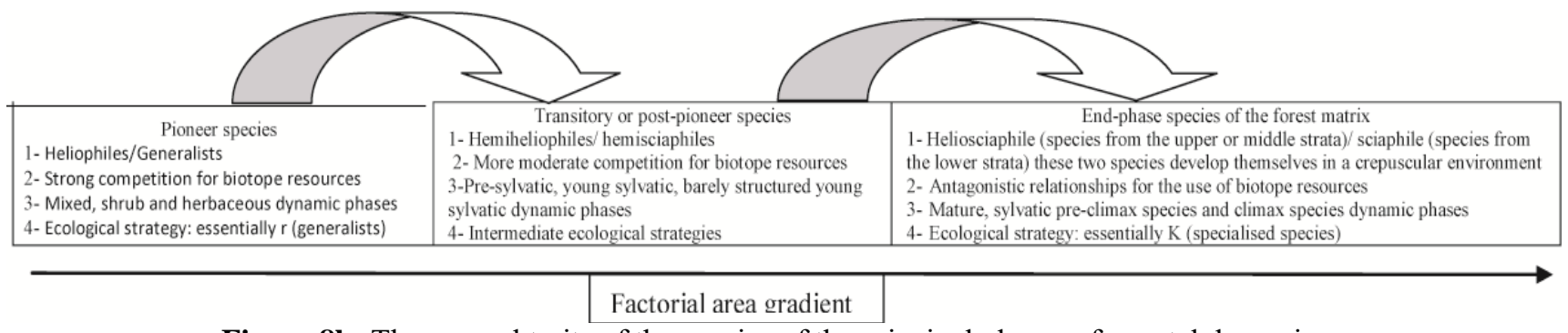

Figure 8b: The general traits of the species of the principal phases of vegetal dynamics
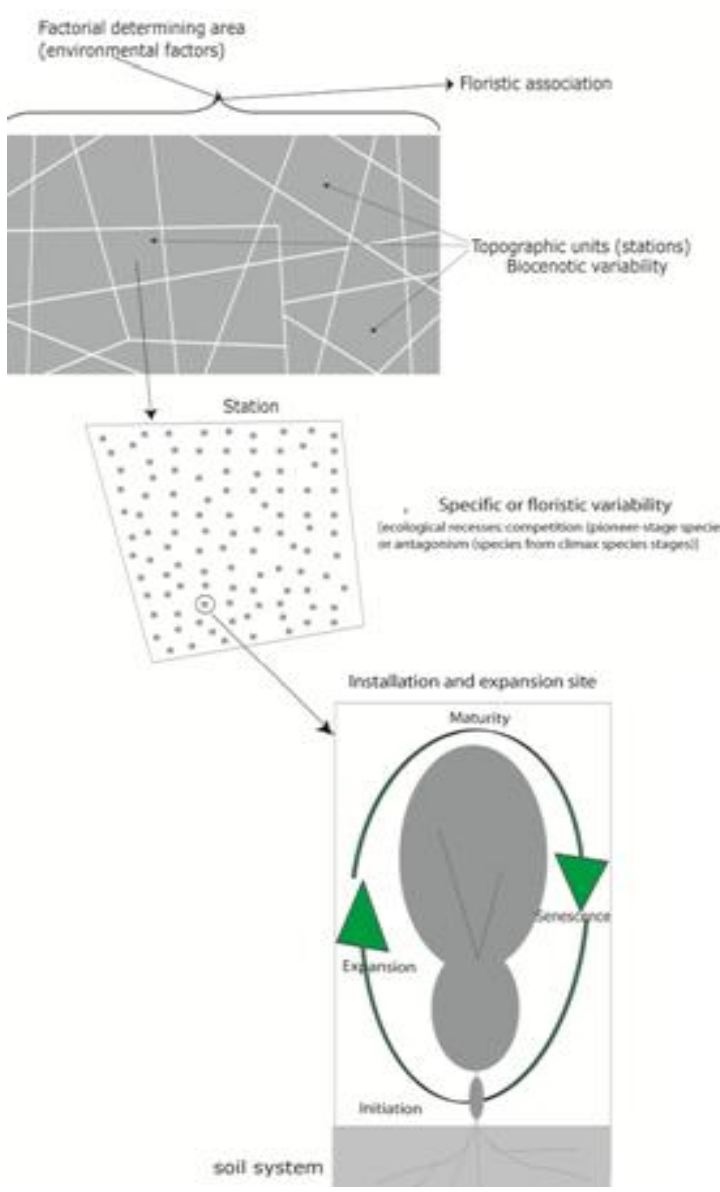

Figure 9: Example of the level of integration in an ecosystem (installation and expansion site)

Volume 4 Issue 11, November 2015

www.ijsr.net 


\section{International Journal of Science and Research (IJSR) \\ ISSN (Online): 2319-7064}

Index Copernicus Value (2013): 6.14 | Impact Factor (2014): 5.611

In the best forest remains, the on going vegetal successions will result in floristic associations dissimilar from what was offered by vegetal cover in the Amerindian era (precolonial) and despite a feasible structural and architectural similarity. Many taxa belonging to previous (mature) ecosystems have disappeared or are now significantly regressing [This is caused by the erosion of biotopes, which simultaneously leads to demographic changes in certain parts of the vector fauna] [30,39]. The successional processes select from a present-day floristic potential (the collection of vegetal species), which is extremely diverse for the young early and secondary species and faintly diverse for advanced secondary and climax species. It is also necessary to mention that the relict advanced secondary and climax species of the primitive sylva are mostly formed of populations of just a few individuals.

According to the hypothesis where certain sectors, which are inaccessible and unsuitable for human activity, reach the climax, the latter will certainly be polyfacies and the architecture of sylvatic vegetal units will be similar to that of the climax from pre-Columbian times (Figure 5). However, they will be made up of species with dynamic profiles from inferior succession phases: more or less generalist. Theoretically, the future predicted climax would be much less complex than the one that matched the conditions in which primitive sylva previously developed.

In general, vegetal succession reaches its final phase when all the floristic potential species have been used as vegetal corteges [27]. The optimal structuring associated with it relies on the great diversity of dynamic profiles. When there are enough of them, alike in the Amerindian era, they give the vegetal cover a high biocenotic malleability for the processes of restoration and complexification [30]. Formerly, natural hazards, such as hurricanes, created fullfledged and long-term forest regeneration factors: they are called structuring elements. From the $17^{\text {th }}$ century, the low levels of human activity lead to an "isolation" of the forest and the overexpression of the impacts of natural hazards, which have become destructuring elements [58].

After some hundred years, or even a millennium, without any disturbance, the "polyclimax" of areas which will be protected from human activity will be based on a profoundly reduced floristic potential and essentially made up of species with dynamic profiles adapted to present-day secondary vegetation. A small number of species from former climaxes diffidently ensuring their permanence in marginal and nonclimax species forest associations could be added [In fact, these taxa are highly specialised and optimise their demography in environments where the installation and expansion sites are antagonistic, which is not a reality for present-day biotopes that bring about interspecific competition] [43]. Many stations with these characteristics are located in sensitive zones in regards to human force. Given the incomprehensive (systemic) environmental management in the Lesser Antilles, these stations are subject to short and long-term extinction. Over time, the decreasing complexity of vegetation causes the structures in place to become more sensitive to the impacts of natural hazards. In this respect, a high number of species that currently contribute to the most advanced forest eco-units, and some of which will be a part of the next climax, are much less resistant and have a shorter life cycle. These present-day matrixes, more or less generalist species, could only establish themselves permanently in forest aisles or chablis of previous sylva climax species from the pre-colonial era.

\subsection{The Influence of Cyclones}

The fragility of forests today makes weather conditions more important and in certain cases their effects are paroxysmal [61,62]. For example, hurricanes David (1979), Hugo (1989) and Dean (2007) led to a significant loss of biomass above ground in various types of forest [63]. Cyclone David caused serious damage in weakly structured secondary woods, particularly those in average altitude mountains subject to high human impact in Martinique and Dominica [64]. The forest formations still show the traces of this catastrophic episode. This was also the case for cyclone Dean in Martinique. In general, many edificator trees of sylva of the time were profoundly damaged. They were broken, topped or fell, increasing the density of forest aisles. When the amount of chablis [When there are many chablis; when they occupy more than $20 \%$ of the total surface of a forest area it becomes unstable and can regress (nonpublished personal data] rises there is higher instability. This negatively affects the structural integrity of forest formations and the resulting effects are also destabilising (edge effects, increase in intra-forest luminosity).

These degradations caused by cyclone David and Dean were disproportionate with those of forest units in Guadeloupe when hurricane Hugo struck (1989). All the forest associations were affected. The winds were so violent that in many forest sectors the number of maimed trees was surprisingly high. On the other hand, in Martinique, Dominica, Guadeloupe and Puerto Rico [58], cyclones David, Hugo and Dean only slightly damaged the most advanced sylvatic ecosystems: mature or old-growth forests as well as climax and sub-climax species forests [61]. This destruction led to broken treetops, partial or complete, but temporary, defoliation and almost certainly an increase in forest aisles as a consequence of tree fall. This occurred without challenging the architectural and structural integrity of the eco-units. It is evident that high density reduces the effects of violent winds. From an aerial and radicular viewpoint, the mechanic resistance of forest areas is just as great as the structuring species, which belong to the final phase.

When the forest ecosystem reaches its most complex state it seems to be less vulnerable to weather conditions. The degradation of crowns in higher layers instigates a reduction in the overall foliar index of affected forest communities and the inner environment gains luminous energy. In these conditions, the pending heliosciaphile matrix varieties develop or, on the contrary certain heliophiles can find some installation and expansion sites. In the Lorrain valley in Martinique, within its evolved tropical ombrophilous submontane eco-units, the frequent distribution of largeleaved Mahoe (Cordia sulcata: Boraginaceae), heliophile species from seasonal secondary evergreen associations, should be analysed. This species seems to have established 


\section{International Journal of Science and Research (IJSR) \\ ISSN (Online): 2319-7064}

Index Copernicus Value (2013): 6.14 | Impact Factor (2014): 5.611

itself, making use of canopy openings caused by cyclonic phenomena. A whole range of elements sustains a frequent opening of the sylvatic vegetal cover: firstly the almost aleatory distribution of stems, secondly all of the largeleaved Mahoe population's individuals belong to the same diametric category. Thus, it is plausible that this largeleaved Mahoe population corresponds to one single wave of site colonisation, which was most certainly created by an atmospheric phenomenon [38].

When the reduction of aerial biomass has not been too heavy, the trees repeat their structure and recover their full development in their installation and expansion sites (nano systems similar to Holdeman 's ecotopes) [This phenomenon would be equivalent to morphogenetic restoration]. The reconstitution of the aboveground phytomass occurs over a decade and causes the regeneration of exogenous heliophile trees, which established themselves when cyclonic winds modified the canopy, to regress. The overall organisation of climax species eco-units sustains itself with a profusion variety, which is minimal. The end-phase species dominate and are mainly regenerated in the sylvatic matrix. These transformations caused by climatic hazards are fundamental for the forest. Profound climatic disturbance [High occurrence intermittent process], which seems to transiently reduce the level of complexity of climax formations, is associated with renewal in the forest aisles [Low occurrence continuous process].

Consequently, the structural transformations of the forest roof mobilise end-phase species which are in a steady state. This renewal mechanism applies to the matrix as much as it does to the forest aisles and can, following the example of the latter, be considered as a sylvigenetic motor. With its temporal dynamics, its mechanisms and the disturbed sylvatic surface, this turn over, related to upper-air disturbance, is different from that which occurs in the chablis. As a result, the Lesser Antillese forest climax species formations present significant differences in comparison to those that are not subject to destructive hurricanes, particularly in the equatorial zone (the Guianas).

The climax would oscillate between two distinct levels of organisation. The first would be an extreme structuring at a maximum level of complexity. That is to say that without powerful hurricanes for a sufficient period of time, the most specific floristic and biocenotic interaction would occur. This would lead to more stability, a large auto-protection capability with regard to climatic hazards, an inner environment or buffered microclimate and high ecosystemic inertia (higher resilience). The second would resemble the lowest possible complexity of the sylvatic climax species ecosystem, which would not compromise its integrity. The cyclones are the main limitations and are used for the sylvigenetic process. This mechanism is important due to the possibility for certain mature-forest edificator species to develop, particularly heliosciaphile. These trees from the upper strata can develop in a faintly lit forest matrix. In extreme structured forest associations, the "hyperclimaxes"or heliosciaphile species, due to the over-specialisation of installation and expansion sites, [This great specialisation of sites leads to notable contradiction among the taxa] struggle to establish themselves permanently in a steady state, or even in a regeneration state [38].

Nowadays, things are fundamentally opposed. The floristic potential is weak. As it is impossible to find sufficiently wide and evolved host associations, the most specialised taxa, a reference to the previous climate, are almost completely absent or are endangered. The sylvatic stations sheltering these relict species are often surrounded by regressive vegetal cover, made up of, in order of importance, shrub, pre-sylvatic and young secondary sylvatic phytocenoses (Table 2). The discontinuity of mature forest units, increased by today's inefficient vector fauna, limit the possibility for final-phase floristic species to disseminate [The fragmentation of biotopes lethally affects the survival methods of certain profoundly specialised, advanced sylva species populations] (Table 2). Hypothetically, in a progressive future evolution, the climax would occur with the most specialised species from the current floristic potential. A climax species ecosystemic organisation would be reached, but it would be much less complex than the Amerindian primitive sylva.

This new hypothetical climax will be formed of species with dynamic profiles that would bind to the chablis of preColumbian sylva. These species are highly sensitive and vulnerable to cyclones, at the roots and over ground. They are not very dense and their average lifecycle is short. Contrary to the pre-Columbian period, the future climax species formations will incorporate paraclimaxes much more, and climatic disturbance, even weak, will be highly destructive and will provoke profound degradation, which is sometimes irreversible [In general, these will challenge the integrity of previously formed climax species formations].

This is a consequence of the lack of interaction possibilities [Here the notion of interaction relates to the notion of connectance. The extent of connectance, which is based on the number of species, defines the hierarchical methods of the species and the biocenosis within the ecosystem] linked to the disappearance or anthropic regression of highly specialised population species of the end phase: those which normally occupy the extreme structured installation and expansion sites [The most complex in factorial terms]. In the manner of the original primitive sylva, the ecosystemic modifications caused by cyclonic winds will not be expressed by a slight rejuvenation mobilising the climax species vegetal potential to reach a "hyperclimax" after a weaker stage of complex climax species. On the contrary, it will induce a regression which will be based on the intensity of the deregulating elements and dynamic phases. The damage, in terms of broken and fallen trees, will be such that the sub-climax species vegetal cover will not be able to sustain itself. As its integrity will not be ensured by the new eco-climatic conditions, the vegetation which will develop will belong to lower, extra or intra-sylvatic successional phases. In the case where a sylva paraclimax species made up of secondary varieties in the light of pre-Columbian sylva is disturbed, there may be inter-phase dynamic jumps with large discrepancies [Evolving from a sylva paraclimax species and after a hurricane, a herbaceous, shrubby or brush vegetation community can develop] in the sense of regressive succession. Inversely, in the case of primitive 


\section{International Journal of Science and Research (IJSR) \\ ISSN (Online): 2319-7064}

Index Copernicus Value (2013): 6.14 | Impact Factor (2014): 5.611

sylva climax species, there is an intra-phase regressive succession and small discrepancies [The transformations of forest organisation would not challenge the integrity of the dynamic phase which is sub-climax species or weakened climax species].

\subsection{The metastable traits of vegetation}

The present-day vegetation on middle and lower layers is the outcome of all destructuring events which have interfered since the beginning of history in the Lesser Antilles 'e . Today, it is still subject to the damage caused by human activity, reinforcing the catastrophic effects of cyclonic phenomena, which occur more and more frequently [The extreme effects of these phenomenon will be heightened by global climatic change]. All of these destabilising elements today, are not likely to enable progressive evolution in the vegetal cover, which is far from its optimal organisation (the climax). The persistence of factors favouring its degradation means that it is part of a constant breakdown process. Thus, this leads the cortege of vegetal species whose dominance is a result of human impact to be implanted. These species could be named "anthropophite" or "anthropophile" as humankind today abridges their ecological prevalence. They illustrate the extent to which floristic communities have become artificial.

From now on it is necessary to consider the anthropogenic factors as threats in their own right which influence the ecosystem"s general dynamic [65-70]. Consequently, they are the main factor, along with the biophysical factors, of the factorial space and will "weigh" heavily in the identity of installation and expansion sites. Anthropisation imposes new ecosystemic limits. In fact, the former sylvatic potential of the vegetal cover is currently mostly pre-sylvatic and shrubby.

Oddly, in the dry bio-climate, over a short period of time, the slow successional processes are confronted with the active and continuous anthropisation of forest formations. Todayes vegetation oscillates between brush, shrub, presylvatic and young faintly structured sylvatic phases. The advanced or delayed secondary pre-climax species and climax species phases are marginal, specifically in the middle and lower layers [This is true for the entire Lesser Antilles] [43]. The grassy formations that follow intense zoo anthropogenic degradations [Sometimes the degradation caused by pastoral activity is almost irreversible] in the driest areas are not seen much. Animals cause the soil to compact, modifying the characteristics and inducing atypical vegetal successions which privilege species that are naturally very scarce. The Mimosa pigra (Redwood, Mimosaceae) is an eloquent example. Subject to the first waves of shrub colonisation, it develops mostly on floors where agricultural and pastoral activity has taken place.

In the light of the elements mentioned above, it appears that the current vegetation's dynamic is blocked or profoundly slowed by human impact. Consequently, the significant ecosystemic transformations, due to the progressive dynamic, particularly in protected areas, could only be observed in several decades, or even over a hundred years. These circumstances have pervaded and continue to pervade the ways of thinking, and unique perception of physiognomy and the functioning of the vegetal world ensues. For example, the lower sections influenced by the dry bioclimate, are assimilated to dry, non-forest vegetation territories, even if they can survive in these small zones where the relief allows sylvatic units to be saved which may have been a part of forest ecosystems from the beginning of colonisation.

As the Lesser Antilles vegetal cover is plural it makes for interesting scientific studies, yet, we are far from understanding how they function in the most minute details. The ecosystemic complexity of the present results in multiple dynamic directions caused by man and the spatial variability of bio-climatic factors. Natural and human hazards overexpose the metastable nature of these systems, modify their structures and heighten their instability. In some ways, humankind, in its actions, increases the intrinsic heterogeneity of vegetal cover and widens the range of "possible successional trajectories". Under anthropogenic influence, the multi-factorial entity represented by the vegetation becomes a "hyperspace" which is difficult or almost impossible to approach. Although the forest potential in the Lesser Antilles is roughly $800-900 \mathrm{~m}$, the lack of knowledge about the initial conditions hinders us from giving an easy description of the diverse aspects of the vegetal dynamic. The graphs shown above that materialise the successional gradient phases do not provide much meaning and are only realistic on a physiognomic level; they provide information about the succession of dominating physiognomy when the vegetation evolves. Nevertheless, the dominant physiognomic traits roughly indicate the complexity of ecological units which structure the landscape. In fact, a landscape distinguished by an abundance of shrub communities amounts to regressive vegetation.

We can deduce that the ecosystem in its entirety [1 Namely, the regional climate, the vegetal cover in its multifaceted phytocenotic factors, the different topographic categories, the diverse components of the edaphic substratum, the anthropic energy and the dissemination process (physical and biological)]will engender installation and expansion sites in constant mutation (Figure 8b). These sites convey the factorial reality and show great spatio-temporal diversity in the archipelago. This remark exposes the real problem faced by biogeographists and ecologists when searching for a common ecosystemic analysis framework in the Lesser Antilles. The information offered above is the result of numerous floristic studies and is only an attempt at classifying vegetal species on the temporal scale. In this regard, the dynamics seen are linked to the organisation of the current vegetal cover as the identified floristic combinatorial depends effectively on the species base (floristic potential) of today. The ecological importance of varieties informs us about the hosting possibility of vegetal formations and thus their biocenotic complexity. The installation and expansion sites are fundamental units, they are the smallest systems that can be analysed and are typical of spatio-temporal configurations of the considered vegetal formation. They are the reason for the extreme diversity of the vegetation"s organisation. From the previous 


\section{International Journal of Science and Research (IJSR) \\ ISSN (Online): 2319-7064 \\ Index Copernicus Value (2013): 6.14 | Impact Factor (2014): 5.611}

developments, two fundamental aspects can be deduced to understand the succession process:

- Firstly, the large difference of the species ${ }^{\text {ee }}$ malleability due to their plural dynamic profiles.

- Secondly, the existence of a change in the taxa strategy during the successional processes, in relation to their ecological importance.

From the "brush" phase to the phase called climax species, the ecological aptitudes change. The primary heliophile species, which dominate in the beginning of vegetal colonisation in regressive structures - or brush and shrub formations -, become gradually less adapted as progress is made towards the vegetation "s most complex organisations. The secondary heliophiles and hemiheliophiles are more accustomed to pre-sylvatic and young structured sylvatic formations. Yet, late secondary and climax species formations, hemi-sciaphile, sciaphile and heliosciaphile temperaments give the species a high level of efficiency for installation or colonisation [43]. Taking the biotopes ${ }^{\text {ee }}$ biophysical traits into account, their "ecological weight" in the various floristic associations (their intrinsic ecological potential) is regulated by intra and interspecific interaction.

Table 2: The principal end-phase species of Lesser Antilles vegetation

\begin{tabular}{|l|l|l|l|}
\hline \multicolumn{1}{|c|}{ Vegetal varieties $($ middle } & \multicolumn{1}{|c|}{ Families } & MES & \multicolumn{1}{c|}{ DI } \\
\hline Aiphanes erosa $(T)$ & Arecaceae & S2 & + \\
\hline Andira inermis & Fabaceae & S2 & ++ \\
\hline Andira sapindoides & Fabaceae & S2 & + \\
\hline Aniba bracteata & Lauraceae & S2 & ++ \\
\hline Antirhea coriacea $(T)$ & Rubiaceae & S3 & + \\
\hline Brosimum alicastrum & Moraceae & S1 & + \\
\hline Buchenavia tetraphylla & Combretaceae & S1 & + \\
\hline Byrsonima spicata $(T)$ & Malpighiaceae & S2 & +++ \\
\hline Calophyllum calaba & Clusiaceae & S2 & +++ \\
\hline Chione venosa & Rubiaceae & S3 & + \\
\hline Chrysophyllum argenteum & Sapotaceae & S2 & +++ \\
\hline Coccoloba swartzii $(T)$ & Polygonaceae & S2 & ++ \\
\hline Cordia alliodora $(T)$ & Boraginaceae & S2 & ++ \\
\hline Cupania americana & Sapindaceae & S2 & ++ \\
\hline Cupania triquetra & Sapindaceae & S2 & + \\
\hline Diospyros revoluta & Ebenaceae & S1 & + \\
\hline Eugenia gregii & Myrtaceae & S3 & ++ \\
\hline Eugenia pseudosidium $(T)$ & Myrtaceae & S2 & ++ \\
\hline Exothea paniculata $(T)$ & Sapindaceae & S2 & + \\
\hline Exostema sanctae luciae(T)- & Rubiaceae & S2 & + \\
\hline Faramea occidentalis & Rubiaceae & S3 & ++ \\
\hline Genipa americana & Rubiaceae & S2 & +++ \\
\hline Guarea glabra & Meliaceae & S2 & + \\
\hline Guarea macrophylla & Meliaceae & S1 & + \\
\hline Guazuma tomentosa $(T)$ & Sterculiaceae & S2 & ++ \\
\hline Guazuma ulmifolia $(T)$ & Sterculiaceae & S2 & ++ \\
\hline Homalium racemosa $(T)$ & Flacourtaiceae & S2 & ++ \\
\hline Hura crepitans & Euphorbiaceae & S1 & + \\
\hline Hymenaea courbaril & Caesalpiniaceae & S1 & + \\
\hline Ilex nitida & Aquifoliaceae & S1 & + \\
\hline Licania leucosepala & Chrysobalanaceae & S1 & + \\
\hline Licania ternatensis & Lauraceae & S1 & + \\
\hline Licaria sericea & Chrysobalanaceae & S1 & + \\
\hline Manilkara bidentata & Sapotaceae & S1 & + \\
\hline Maytenus guianensis & Celastraceae & S2 & ++ \\
\hline Myrcia fallax $(T)$ & Myrtaceae & S2 & + \\
\hline Myrcia leptoclada $(T)$ & & S3 & + \\
\hline
\end{tabular}

\begin{tabular}{|c|c|c|c|}
\hline Myrcia pla tyclada & Myrtaceae & S3 & ++ \\
\hline Ocotea leucoxylon $(T)$ & Lauraceae & S2 & ++ \\
\hline Ormosia monosperma & Fabaceae & $\mathrm{S} 2$ & ++ \\
\hline Oxandra laurifolia & Annonaceae & $\mathrm{S} 2$ & + \\
\hline Picramnia pentandra & Simaroubaceae & S3 & +++ \\
\hline Picrasma excelsa $(T)$ & Simaroubaceae & S3 & + \\
\hline Pithecellobium jupunba & Mimosaceae & $\mathrm{S} 2$ & + \\
\hline Pouteria multiflora & Sapotaceae & S1 & +++ \\
\hline Pouteria semecarpifolia & Sapotaceae & S1 & + \\
\hline Prestoea montana & Arecaceae & $\mathrm{S} 2$ & ++ \\
\hline Quararibea turbinata & Bombacaceae & S3 & +++ \\
\hline Rhytococos amara & Arecaceae & $\mathrm{S} 2$ & + \\
\hline Simaruba amara (T) & Simaroubaceae & S1 & ++++ \\
\hline Sterculia caribaea & Sterculiaceae & S1 & ++ \\
\hline Swartzia simplex & Caesalpiniaceae & S1 & + \\
\hline Vitex divaricata & Verbénaceae & S1 & ++ \\
\hline Zanthoxylum flavum & Rutaceae & $\mathrm{S} 2$ & + \\
\hline Protium attenuatum & Burseraceae & $\mathrm{S} 2$ & ++ \\
\hline Amanoa caribaea & Euphorbiaceae & S2 & ++ \\
\hline Aniba bracteata & Lauraceae & S2 & ++ \\
\hline Aniba ramageana & Lauraceae & S3 & + \\
\hline Beilschmiedia pendula & Lauraceae & S1 & + \\
\hline Calyptranthes fasciculata & Myrtaceae & S3 & ++ \\
\hline Cassipourea guianensis & Rhizophoraceae & S3 & +++ \\
\hline Chimarrhis cymosa & Rubiaceae & S1 & ++++ \\
\hline Chione venosa & Rubiaceae & S3 & + \\
\hline Cyathea tenera & Cyatheaceae & S3 & + \\
\hline Cyathea muricata & Cyatheaceae & S3 & + \\
\hline Dacryodes excelsa & Burserarceae & S1 & +++ \\
\hline Diopyros revoluta & Ebenaceae & $\mathrm{S} 2$ & + \\
\hline Drypetes dussii & Euphorbiaceae & S3 & + \\
\hline Endlicheria sericea & Lauraceae & S3 & + \\
\hline Eugenia albicans & Myrtaceae & S3 & ++ \\
\hline Eugenia chrysobalanoides & Myrtaceae & S3 & + \\
\hline Eugenia coffeifolia & Myrtaceae & S3 & + \\
\hline Eugenia domingensis & Myrtaceae & S1 & + \\
\hline Eugenia grypospermea & Myrtaceae & S3 & + \\
\hline Eugenia octopleura & Myrtaceae & S3 & + \\
\hline Eugenia oerstedeana & Myrtaceae & S3 & + \\
\hline Euterpe dominicana & Arecaceae & S3 & + \\
\hline Geonoma dussiana & Arecaceae & S3 & + \\
\hline Geonoma martinicensis & Arecaceae & S3 & + \\
\hline Guatteria caribaea & Annonaceae & S1 & ++ \\
\hline Heisteria coccinea & Olacaceae & $S 1$ & ++ \\
\hline Hirtella triandra & Chrysobalanaceae & $\mathrm{S} 2$ & ++ \\
\hline Ilex sideroxyloides & Aquifoliaceae & $\mathrm{S} 2$ & ++ \\
\hline Licania leucosepala & Chrysobalanaceae & S1 & + \\
\hline Licania ternatensis & Chrysobalanaceae & S1 & +++ \\
\hline Meliosma herbertii & Sabiaceae & S1 & + \\
\hline Meliosma pardonii & Sabiaceae & $\mathrm{S} 2$ & + \\
\hline Micropholis guyanensis & Sapotaceae & S1 & +++ \\
\hline Ocotea martinicensis & Lauraceae & S2 & + \\
\hline Oxandra laurifolia (*) & Annonaceae & $\mathrm{S} 2$ & + \\
\hline Phyllanthus mimosoides & Euphorbiaceae & S3 & + \\
\hline Podocarpus coriaceus & Podocarpaceae & S2 & ++ \\
\hline Pouteria multiflora & Sapotaceae & S1 & ++ \\
\hline Pouteria pallida & Sapotaceae & S1 & + \\
\hline Pouteria semecarpifolia & Sapotaceae & S1 & ++ \\
\hline Prestoea montana & Arecaceae & $\mathrm{S} 2$ & ++ \\
\hline Prunus pleuradenia & Rosaceae & S1 & + \\
\hline Richeria grandis & Euphorbiaceae & $\mathrm{S} 2$ & ++ \\
\hline Sloanea berteriana & Elaeocarpaceae & S1 & + \\
\hline Sloanea caribaea & Elaeocarpaceae & S1 & ++ \\
\hline Sloanea dentata & Elaeocarpaceae & S1 & +++ \\
\hline Sloanea dussii & Elaeocarpaceae & S1 & + \\
\hline Sloanea massoni & Elaeocarpaceae & S1 & +++ \\
\hline Sterculia caribaea & Sterculiacaeae & S1 & +++ \\
\hline
\end{tabular}




\section{International Journal of Science and Research (IJSR) \\ ISSN (Online): 2319-7064}

Index Copernicus Value (2013): 6.14 | Impact Factor (2014): 5.611

\begin{tabular}{|c|c|c|c|}
\hline Styrax glaber & Styracaceae & S2 & + \\
\hline Swartzia caribaea & Caesalpiniaceae & $\mathrm{S} 2$ & + \\
\hline Talauma dodecapetala & Magnoliaceae & S1 & ++ \\
\hline Tapura latifolia & Dichapetalaceae & $\mathrm{S} 1$ & +++ \\
\hline Tovomita plumieri & Clusiaceae & S3 & ++++ \\
\hline Weinmannia pinnata & Cunoniaceae & S3 & + \\
\hline Amyris elemifera & Rutaceae & S3 & ++++ \\
\hline Andira inermis & Fabaceae & S1 & ++ \\
\hline Antirhea coriacea (*) & Rubiaceae & S3 & + \\
\hline Brosimum alicastrum (*) & Moraceae & S1 & + \\
\hline Buchenavia tetraphylla (*) & Combretaceae & S1 & + \\
\hline Callophyllum calaba (*) & Clusiaseae & $\mathrm{S} 2$ & ++ \\
\hline Cassipourea guianensis & Rhizophoraceae & S3 & +++ \\
\hline Chione venosa (*) & Rubiaceae & S3 & + \\
\hline Cupania americana (*) & Sapindaceae & $\mathrm{S} 2$ & ++ \\
\hline Cupania tiquetra (*) & Sapindaceae & $\mathrm{S} 2$ & + \\
\hline Diospyros revoluta & Ebenaceae & $\mathrm{S} 2$ & + \\
\hline Eugenia tapacumensis & Myrtaceae & S3 & + \\
\hline Genipa americana & Rubiaceae & $\mathrm{S} 2$ & +++ \\
\hline Guaiacum officinale & Zygophyllaceae & $\mathrm{S} 2$ & + \\
\hline Guarea glabra (*) & Meliaceae & $\mathrm{S} 2$ & + \\
\hline Homalium racemosum (*) & Flacourtiaceae & S1 & + \\
\hline Hymenaea courbaril & Caesalpiniaceae & S1 & + \\
\hline Ilex nitida (*) & Aquifoliaceae & S1 & + \\
\hline Krugiodendron ferreum & Rhamnaceae & $\mathrm{S} 2$ & + \\
\hline Licania leucosepala (*) & Chrysobalanceae & S1 & + \\
\hline Licaria sericea $(*)$ & Lauraceae & S1 & + \\
\hline Manilkara bidentata (*) & Sapotaceae & S1 & + \\
\hline Maytenus grenadensis & Celastraceae & $? /$ & + \\
\hline Maytenus guianensis (*) & Celastraceae & $? /$ & + \\
\hline Maytenus laevigata & Celastraceae & S1 & ++ \\
\hline Myrcianthes fragrans & Myrtaceae & $\mathrm{S} 2$ & + \\
\hline Ocotea coriacea & Lauraceae & $\mathrm{S} 2$ & ++ \\
\hline Ormosia monosperma & Fabaceae & $\mathrm{S} 1$ & ++ \\
\hline Pimenta racemosa & Myrtaceae & S1 & +++ \\
\hline Pithecellobium jupunba & Mimosaceae & S3 & + \\
\hline Pouteria multiflora $(*)$ & Sapotaceae & S1 & + \\
\hline Pouteria semecarpifolia (*) & Sapotaceae & $\mathrm{S} 1$ & + \\
\hline Protium attenuatum (*) & Burseraceae & $\mathrm{S} 2$ & + \\
\hline Sideroxylon foetidissimum & Sapotaceae & S1 & + \\
\hline Sideroxylon obovatum & Sapotaceae & $\mathrm{S} 2$ & + \\
\hline Sideroxylon salicifolia & Sapotaceae & S3 & + \\
\hline Sterculia caribaea & Sterculiaceae & S1 & + \\
\hline Swartzia simplex (*) & Caesalpiniaceae & $\mathrm{S} 2$ & + \\
\hline
\end{tabular}

(*): Species on the middle of upper layer in the peripheral zone in the late or climax species eco-units of the lower level/ (T): Species whose demographic dynamic is stimulated by canopy openings (forest aisles or chablis) IMES: Maximum Expansion Strata / S1: Upper strata / S2: Middle strata / S3: Lower strata / ID (plausible Demographic Importance for the entire Lesser Antilles): + (very weak population)/ ++ (weak population) / +++ (average population)/ ++++ (quite large population)/ +++++ (large population). This qualitative index of the population does not indicate the way taxa individuals are distributed or their diametric or biomass categories. The absence of a species on certain islands does not mean that the species never existed. There are grounds to believe that in many cases this absence is a result of the disappearance of biotopes (particularly if there weren't many of them) and/or the low number of populations.

\section{Conclusion}

Thus, during the vegetal dynamic, species with varying ecologic and demographic importance (distribution and dominance) interfere. Families of a "photic disposition" succeed one another over time and define, at each big succession stage, periods in which one family will dominate another. From the beginning to the end of the dynamic, we could roughly define: the heliophile era, the hemi-heliophile era, the hemi-sciaphile era, finally the heliosciaphile era and the sciaphile era (sylva climax species). In theory, at the end of vegetal succession, the forest aisles become "refuge areas" in which mostly heliophile species that cannot find installation and expansion potential elsewhere, are sustained. This functioning of the forest ecosystem ensures that its structure gives all the possible solutions in the event of degradation; as soon as its integrity is not challenged by strong disturbance or deregulation [ 1 The ecosystemic integrity refers to resilience and thus the ability to weaken fluctuations in the external environment. These can be natural and/or anthropic]. Aside from their sylvigenetic renewal role, the chablis act as floristic reserves where restoration can be initiated.

In the small forest plots, the new forest aisles, according to their dimensions, are colonised by diaspores, which come from degraded peripheral areas and/or previously established forest aisles going through the "scarring" process. Conversely, within large forest massifs, the new chablis are mainly colonised by airborne or zoochory (often ornithochory) seeds coming from their own forest aisles. From the centre to the periphery, they induce a more or less significant variety of physical factors and determine the spatial distribution of floristic corteges. Over time, the restoration mechanism is expressed by a floristic succession going from brief cicatricial to sustainable species going through a series of lifecycle degrees. In general, the cicatricial long-lived species appear at the end of restoration - at the end of restorer succession - and can survive for a long time in the forest matrix [71].

\section{Acknowledgments}

This paper was backed by the l'Université des Antilles Françaises.

\section{References}

[1] del Moral R, Saura JM and Emenegger JN. Primary succession trajectories on a barren plain, Mount St. Helens, Washington. Journal of Vegetation Science. 21: 857-867 (2010).

[2] Delcourt HR, Delcourt PA, Webb T. Dynamic plant ecology: the spectrum of vegetation change in time and space. Quaternary Science Reviews. 1: 153-175 (1983).

[3] Hobbs RJ, Suding KN (eds). New Models for Ecosystem Dynamics and Restoration. Washington, DC: Island Press (2009).

[4] Phillips J. Succession, development, the climax and the complex organism: an analysis of concepts.I. Journal of Ecology. 22: 554-571 (1934). 


\section{International Journal of Science and Research (IJSR) \\ ISSN (Online): 2319-7064}

Index Copernicus Value (2013): 6.14 | Impact Factor (2014): 5.611

[5] Phillips J. Succession, development, the climax and the complex organism: an analysis of concepts. II. Journal of Ecology. 23: 210-246 (1935a).

[6] Phillips J. Succession, development, the climax and the complex organism: an analysis of concepts. III. Journal of Ecology.23: 488-508 (1935b).

[7] Aide TM, Zimmerman J K, Pascarella JB, Rivera L, Marcano-Vega H. Forest regeneration in a chronosequence of tropical abandoned pastures: implications for restoration ecology. Restoration ecology. 8(4), 328-338 (2000).

[8] Acevedo MF, Urban DL, Shugart HH. Models of forest dynamics based on roles of tree species. Ecological Modelling. 87: 267-284 (1996).

[9] Drury WH, Nisbet ICT. Succession. Journal of the Arnold Arboretum. 54: 331-368 (1973).

[10] Horn HS. Forest succession. Scientific American. 232: 90-98 (1975).

[11]Blew RD. On the definition of ecosystem. Bulletin of the Ecological Society of America. 171-173 (1996).

[12] Anderson KJ. Temporal patterns in rates of community change during succession. The American Naturalist. 169: 780-793 (2007).

[13] Callaway RM, Walker LR. Competition and facilitation: a synthetic approach to interactions in plant communities. Ecology. 78: 1958-1965 (1997).

[14] del Moral R, Eckert AJ. Colonization of volcanic deserts from productive patches. American Journal of Botany. 92: 27-26 (2005).

[15] del Moral R. Limits to convergence of vegetation during early primary succession. Journal of Vegetation Science. 18: 479-488 (2007).

[16] Attiwill PM. The disturbance of forest ecosystems, the ecological basis for conservative management. Forest Ecology and Management. 63: 247-300 (1994).

[17] Bardgett R. The Biology of Soil: A Community and Ecosystem Approach. Oxford: Oxford University Press. (2005).

[18] Bormann FH, Likens GE. Pattern and Process in a Forested Ecosystem. New York: Springer-Verlag (1979).

[19]Clements FE. Plant Succession and Indicators: A Definitive Edition of Plant Succession and Plant Indicators. New York: HW Wilson (1928).

[20] Crews T, Kitayama K, Fownes J et al. Changes in soil phosphorus fractions and ecosystem dynamics across a long chronosequence in Hawaii. Ecology. 76: 14071424 (1995).

[21] del Moral R, Sandler JE, Muerdter CP. Spatial factors affect primary succession on the Muddy River Lahar, Mount St. Helens, Washington. Plant Ecology. 201: 177-190 (2009).

[22] Burrows CJ. Processes of Vegetation Change. London: Unwin Hyman (1990).

[23] del Moral R, Grishin SY. Volcanic disturbances and ecosystem recovery. In: Walker LR (ed.) Ecosystems of Disturbed Ground. Ecosystems of the World 16, pp. 137-160. Amsterdam: Elsevier (1999).

[24] del Moral R, Walker LR. Environmental Disasters, Natural Recovery and Human Responses. Cambridge: Cambridge University Press ( 2007).

[25] Clements FE. Nature and structure of the climax. Journal of Ecology. 24: 252-284 (1936).
[26] Connell JH, Slatyer RO. Mechanisms of succession in natural communities and their role in community stability and organization. The American Naturalist. 111: 1119-1144 (1977).

[27] Shugart HH. A Theory of Forest Dynamics: The Ecological Implications of Forest Succession Models. Caldwell, New Jersey: Blackburn Press. 2003.

[28] Meeker Jr, DO, Merkel, DL. Climax theories and a recommendation for vegetation classification: a viewpoint. Journal of Range Management. 1984; 427430.

[29] Santiago-Valentin E, Olmstead RG. Historical biogeography of Caribbean plants: introduction to current knowledge and possibilities from a phylogenetic perspective. Taxon. 53:299-319 (2004)

[30] Joseph P. The vegetation of the Lesser Antilles: floristic diversity and ecosystemic dynamics. International Journal of Environmental Studies. 69(5), 816-833 (2012 a).

[31] Acevedo-Rodríguez P, Strong M T. Floristic richness and affinities in the West Indies. The Botanical Review. 74(1), 5-36 (2008).

[32] Migeot J, Imbert D. Structural and floristic patterns in tropical swamp forests: A case study from the Pterocarpus officinalis (Jacq.) forest in Guadeloupe, French West Indies. Aquatic botany. 94(1), 1-8 (2011).

[33] Howard RA. Flora of the Lesser Antilles: Leeward and Windward Islands. Volume 3: Monocotyledoneae. Jamaica Plain, MA: Arnold Arboretum Press of Harvard University (1979).

[34] Howard RA. Flora of the Lesser Antilles: Leeward and Windward Islands. Volume 4: Dicotyledoneae-Part 1. Jamaica Plain, MA: Arnold Arboretum Press of Harvard University (1988).

[35] Howard RA. Flora of the Lesser Antilles: Leeward and Windward Islands. Volume 4: Dicotyledoneae-Part 2. Jamaica Plain, MA: Arnold Arboretum Press of Harvard University (1989a).

[36] Howard RA Flora of the Lesser Antilles: Leeward and Windward Islands. Volume 4: Dicotyledoneae-Part 3. Jamaica Plain, MA: Arnold Arboretum Press of Harvard University (1989b).

[37] Swenson NG, Umaña MN. Phylofloristics: an example from the Lesser Antilles. Journal of Plant Ecology. 7(2), 166-175 (2014).

[38] Joseph P. Dynamique, écophysiologie végétales en bioclimat sec à la Martinique. Thèse de doctorat, Université des Antilles et de la Guyane, Septentrion Presses universitaires, Lille- France (Thèse à la carte) (1997).

[39] Joseph P. Quelques traits généraux de la diversité sylvatique des Petites Antilles . VertigO.; URL :http://vertigo.revues.org/12492

[40] Joseph P. How Should the Forest Types of the Lesser Antilles be Described in the Intertropical Area?. Earth Resources. 2013; 1(3), 78-102.

[41]Beard JS. The progress of plant succession on the Soufriere of St. Vincent: observations in 1972. Vegetatio. 31(2), 69-77 (1976).

[42] Lugo AE, Medina E, Trejo-Torres JC, Helmer E. Botanical and Ecological Basis for the Resilience of Antillean Dry Forests. Neotropical Savannas and 


\section{International Journal of Science and Research (IJSR) \\ ISSN (Online): 2319-7064}

Index Copernicus Value (2013): 6.14 | Impact Factor (2014): 5.611

Seasonally Dry Forests: Plant Diversity, Biogeography, and Conservation (2006).

[43] Joseph P. Structure of vegetation formations and floral dynamics in the Lesser Antilles: The example of the lower vegetation level of Martinique. The Journal of Ecology. (Photon). 109 : 375-400 (2014b).

[44] Joseph P. La végétation forestière des Petites Antilles: synthèse biogéographique et écologique, bilan et perspectives. KARTHALA Editions (2009).

[45] Frontier S. Réflexions pour une théorie des écosystèmes. Bull. E d. 8(4), 445-464 (1977).

[46] Cole .LES, Bhagwat SA, Willis KJ. Long-term disturbance dynamics and resilience of tropical peat swamp forests. Journal of Ecology. 103: 16-30 (2015).

[47] Reyer CPO, Brouwers N, Rammig A, Brook BW, Epila J, Grant RF, Holmgren M, Langerwisch F, Leuzinger S , Lucht CW, Medlyn B, Pfeifer M, Steinkamp J, Vanderwe MC, Verbeeck H, Villela DM. Forest resilience and tipping points at different spatio-temporal scales: approaches and challenges. Journal of Ecology., 103, 5-15 (2015a).

[48] Reyer C PO, Rammig A, Brouwers N, Langerwisch F. Forest resilience, tipping points and global change processes. Journal of Ecology. 2015b; 103: 1, 1-4

[49] Joseph P. The Influence of Vegetation on the Main Macro-Climatic Factors: the Example of the Lower Vegetal Floor of Martinique (Lesser Antilles). Open Jounal of Botany (OJB). 1(1):5-18 (2014a).

[50]Beard JS. Climax vegetation of tropical America. Ecology. 25:127-158 (1944).

[51] Westman WE. Edaphic climax pattern of the pygmy forest region of California. Ecological Monographs. 109-135 (1975).

[52] Walker LR, Wardle DA, Bardgett RD et al. The use of chronosequences in studies of ecological succession and soil development. Journal of Ecology. 98: 725-736 (2010).

[53] Pfister R D, Arno SF. Classifying forest habitat types based on potential climax vegetation. Forest Science. 26(1), 52-70 (1980).

[54]Niering WA. Vegetation dynamics (succession and climax) in relation to plant community management. Conservation Biology. 1(4), 287-295 (1987).

[55]Lugo AE, Schmidt R, Brown S. Tropical forests in the Caribbean. Ambio. 318-324 (1981).

[56] Chen J, Saunders SC, Crow TR, Naiman RJ, Brosofske KD, Mroz GD, ... , Franklin JF. Microclimate in Forest Ecosystem and Landscape Ecology Variations in local climate can be used to monitor and compare the effects of different management regimes. BioScience. 49(4), 288-297 (1999).

[57] Gibson DJ. Textbook misconceptions: the climax concept of succession. The American Biology Teacher. 135-140 (1996).

[58] Weaver PL. Hurricane damage and recovery in the montane forests of the Luquillo Mountains of Puerto Rico. Caribbean Journal of Science. 22(1-2), 53-70 (1986).

[59] Sprugel DG. Disturbance, equilibrium, and environmental variability: what is ,natural ${ }^{e}$ vegetation in a changing environment?. Biological conservation. 58(1), 1-18 (1991).
[60] Dobson AP, Bradshaw AD, Baker AJM. Hopes for the future: restoration ecology and conservation biology. Science. 277: 515-522 (1997).

[61] Imbert D, Portecop J. Hurricane disturbance and forest resilience: assessing structural vs. functional changes in a Caribbean dry forest. Forest Ecology and Management. 255(8), 3494-3501 (2008).

[62] Glenn ME, \& Bensen KJ. Forest structure and tree species composition of the Grand Etang Forest on Grenada, West Indies, pre-Hurricane Ivan. Caribbean Journal of Science. 44(3), 395-401 (2008).

[63] Imbert D, Labbe P, Rousteau A. Hurricane damage and forest structure in Guadeloupe, French West Indies. Journal of Tropical Ecology. 12(05), 663-680 (1996).

[64] Lugo AE, Applefield M, Pool D J, McDonald RB. The impact of Hurricane David on the forests of Dominica. Canadian Journal of Forest Research. 13(2), 201211(1983).

[65] Prach K, Walker LR. Four opportunities for studies of ecological succession. Trends in Ecology and Evolution. 26: 119-123 (.2011).

[66] Noble IR, Slatyer RO. The use of vital attributes to predict successional changes in plant communities subject to recurrent disturbances. Vegetatio. 43: 5-21 (1980).

[67] Meiners, SJ, Rye, TA, Klass, JR. On a level field: the utility of studying native and non-native species in successional systems. Applied Vegetation Science. vol. 12, no 1, 45-53 (2009).

[68] Johnson EA, Miyanishi K. Plant Disturbance Ecology: The Process and the Response. Amsterdam: Academic Press (2007).

[69] Johnson EA, Miyanishi K. Testing the assumptions of chronosequences in succession. Ecology Letters. 11: 419-431 (2008).

[70] Joseph P. Attempt to understand the relationship between the water of the soil system and the vegetation: the case of the Martinique lower vegetation floor. Journal of Advances in Biology (Council for Innovative Research). Vol. (3), 1161-1188 (2015).

[71] del Moral R, Walker LR, Bakker JP. Insights gained from succession for the restoration of landscape structure and function. In: Walker LR, Walker $\mathrm{J}$ and Hobbs RJ (eds) Linking. Restoration and Ecological Succession, pp. 19-44. New York: Springer (2007). 